\title{
UNIVERSITY LIBRARIES AND ITS ROLE IN UNDERGRADUATE STUDENTS LEARNING: THE CHALLENGE OF LISTENING TO ALL VOICES
}

\author{
A. Rivera-Aguilera ${ }^{1}$, G. Solano-Aguilar², S. Salazar-Robles ${ }^{2}$, M. Herrera', A. \\ Cruz-Vázquez ${ }^{2}$ \\ ${ }^{1}$ Universidad Iberoamericana Ciudad de México (MEXICO) \\ 2ITESO, Universidad Jesuita de Guadalajara (MEXICO)
}

\begin{abstract}
From a mixed methodological perspective (qualitative and quantitative), our study seeks to learn the role of academic libraries in two different private universities of Jesuit orientation in Mexico. In order to achieve this goal, it is necessary to establish samples that accurately represent undergraduate students from a diversity perspective. Common characteristics comprehending: academic programs, period of study, bilingualism, nationality, place of origin, ethnicity, disability and sexual orientation, are already demographic data that needs to be considered in studies that address diversity. However, based on qualitative exploratory data, more information has emerged from a shared context, in order to sample diversity such as: having chosen their program of study, feeling comfortable being students, being foreigners, practicing sports, being workers or having siblings, among others. This diversity approach could guide services design, collections and library spaces. Furthermore, both libraries might offer services more specifically aimed at the education of students in accordance with their different characteristics and needs.
\end{abstract}

Keywords: University libraries, Higher education, User studies, Undergraduate students, Research methodology, Qualitative studies.

\section{INTRODUCTION}

Library studies traditionally report quantitative data on resources use and user's satisfaction that are very useful to improve service quality, collection development, report integration and up-to-date materials. Although the role of these results is perceived to be important in higher education, they are expensive and focused mainly on access, both to printed materials and digital sources of information. Even if these studies sometimes look onto the development of information skills, their results tend to be unclear and considered as supplementary, in association to the complex processes of teaching and learning that occur in universities.

Although process design, and the implementation of services and collections considers students as users, this approach normally takes into account only their general characteristics, not those qualitative aspects that could enhance the role of libraries in their university training according to their specific needs. Students being served as patrons in university libraries come from different backgrounds and cultures.

Once we have managed to learn some students' narratives on their general education process, we believe that it is possible to identify library-related matters in their stories, pieces that will allow us to have more elements to define effective and relevant strategies. Without a doubt, these strategies will be useful to strengthen the role of the library in the development of critical thinking among students and in different ways could articulate educational actions with different disciplines and University contexts.

In recent decades, the presence of the digital sphere has modified the library's internal processes and as well as users, interactions have led us to find us increasingly immersed in digital culture. In parallel, we observe a growing need for the development of information management skills. Alonso Arévalo [1], in a compilation of Anglo-Saxon trends on libraries, tells us that libraries are adapting, as well as all of society, to new forms of behavior and users' needs of information. The new library spaces offer tools and technologies that support the learning, discovery, creation and experimentation. 
In the case of the libraries of the Jesuit University System of Mexico (SUJ), we have the mission to assist in the comprehensive training of students to be professionals who are committed towards the needs of today's society. For that purpose, is essential for libraries to take responsibility in developing a high level of information literacy among students. This project arises from the need to understand the role of libraries in the learning process of undergraduate students in the libraries of two private universities that are part of the SUJ, therefore in each library teachers, librarians, and academics formed a research group.

Services and collections in our libraries offer different formats in which print and digital formats share a space. This condition has caused our libraries to experience changes in the storage and distribution forms for informative contents. However, contrary to what could be supposed, with the arrival of electronic information, the use of Internet and of the large search engines for information services, the University Library has not been misplaced but rather reconfigured according to the new offer and new consultation needs.

At the same time, in the broader context of our educational work, the number of users from different backgrounds in terms of basic and high school education has increased in our institutions. This makes it even more difficult to assess the impact of information uses in education and, on the other hand, requires us to keep asking what we have to do as libraries in the midst of a context saturated with content and recovery channels.

It is a fact that the university libraries in which we work are still offering to academic content creators great physical and virtual spaces, both for individual and collaborative work. They also offer collections and information services to external users and of course, mostly to young students between the ages of 18 and 22.

Taking into account other contexts, we observe that in the 2016 American Library Association (ALA) Report on the State of Libraries [2] is possible to identify aspects of the current situation of American libraries and this allows us to note similar concerns globally and in Latin America. The information in this ALA report [2] allows us to infer that a premise on the work of libraries is that they must be valued more for what they do to people than for what they have in their collections. This view matches the quest to define more clearly the role of the library in the University education through the comprehensive recognition of the needs of information and the parameters of information literacy of students from different programs and levels of studies that coexist in the University.

From these aspects, we confirm that library professionals could promote more opportunities [2] for individuals and the progress of the study communities if they manage to bring value to the practices of their users. According to ALA, all kinds libraries add value to their users in 5 areas: education, employment, entrepreneurship, empowerment and involvement. Libraries, points ALA [2], consolidate the legacy of reading and the development to form an inclusive digital society.

According to Gazzolo [3] is important to not only offer new and more ambitious services in the University Library, but also to address its impact on the students' education. This author suggests new statistical indicators, such as: 1 . To correlate the visits to the library with the scores of the students, or compare the grade averages from students who visit the library with those who are not visitors. 2 . In the same way, to analyze the relationship between desertions, titling time and success of minority groups with book loans, use of databases, consultation services, etc. In the initial research report that we share in this paper, one of our priority objectives is to identify most of undergraduate students groups, both majorities and minorities.

The Association of College and Research Libraries (ACRL) in the United States, as a division of ALA, has developed since 2013 a program called Assessment in Action (AiA) oriented towards evaluation processes on the different fields of action within a library. Because of this program, the ACRL has found a body of evidence from research showing results on the positive contributions of academic libraries in student learning [4], [5]. These approaches have been valuable to us because of the concrete evidence showing the impact of the library in the academic results of students, as well as for the methods designed and already used to build this type of evidence. However, we believe that efforts such as AiA could be broadened by an approach that observes what happens in classrooms, laboratories and in each relevant area of college campuses, because we seek to detect finer elements to assess the role of the library in a comprehensive university education. We detected that listening to what is important to students about 
their training might also be necessary to identify this role and to correlate the library functions with other potential areas of impact.

\section{METHODOLOGY}

The theoretical-methodological perspective derives from a mixed approach based on Grounded Theory linked to Symbolic Interactionism and Constructivism. Under this perspective, we started the recovery of qualitative data for the construction of analytical categories and the subsequent delimitation of representative levels from comparable quantitative data from both universities, one in Mexico City and another in the city of Guadalajara, both in Mexico.

The reference found in Glaser and Strauss [6] was then enriched by Charmaz's perspective [7] and allowed us to compare what we think about the theoretical basis of Symbolic Interactionism proposed by Mead [8], and developed by Blumer [9]. At the same time, we realized that the Grounded Theory method does require the identification of categories, but especially of relations resulting from the fine analysis of the stories. In these cases, those relations seemed relevant to identify the students' qualities that we believe could relate with their university life and mainly with their forms of study. Conceptually this approach will involve:

- Open initial coding of actions and processes reported since the beginning of data collection.

- Grouping and laying out of codes into families, conceptualizing these codes for them to become explanatory categories and identifying the relationships between codes.

- Focused coding using families and the same timing enriching each one of them with more data and relationships.

- Constant reflective writing in dialogue with the narrative, the thought of the researcher and pertinent literature.

- Construction of an explanatory model of the object of study.

For now, we have only worked in achieving correspondence between the approach, the process and the results in the different phases described in Table 1.

Table 1. Correspondence in Each Phase of the Research Process

\begin{tabular}{|c|c|}
\hline Data Collection & Construction of References \\
\hline $\begin{array}{c}\text { Demographic data that will allow us to } \\
\text { observe different social markers and its } \\
\text { variety: socio-cultural, economic, gender, } \\
\text { geographical origin and lifestyle related } \\
\text { aspects. }\end{array}$ & $\begin{array}{l}\text { Creation of qualitative models regarding the } \\
\text { role of the library in the University education } \\
\text { resulting from students' voices }\end{array}$ \\
\hline $\begin{array}{l}\text { Representative cases for the application of } \\
\text { in-depth interviews and focus groups. }\end{array}$ & $\begin{array}{l}\text { Creation of qualitative models regarding the } \\
\text { role of the library in the University education } \\
\text { from the factors affecting in this role }\end{array}$ \\
\hline $\begin{array}{l}\text { Systematization of Experiences Seminar in } \\
\text { each University for students to describe their } \\
\text { experiences in diaries to integrate them as } \\
\text { stories, and integrate them as part of the } \\
\text { different voices. }\end{array}$ & $\begin{array}{l}\text { A survey with a representative sample in each } \\
\text { institution will be held in order to develop a } \\
\text { factor analysis to validate and enrich the } \\
\text { qualitative model and identify correlations } \\
\text { between variables. }\end{array}$ \\
\hline $\begin{array}{l}\text { An analysis of Grounded Theory will take } \\
\text { place simultaneously to data collection. From } \\
\text { this analysis theoretical sampling will be } \\
\text { reached, understood as the saturation of the } \\
\text { analyzed categories. }\end{array}$ & $\begin{array}{l}\text { The research question is What is the role of } \\
\text { University libraries in the education of } \\
\text { undergraduate students? } \\
\text { The objectives that have been addressed so } \\
\text { far are: } \\
\text { 1. To Identify diversity in undergraduate } \\
\text { students. } \\
\text { 2. List library collections and services. }\end{array}$ \\
\hline
\end{tabular}




\author{
3. Analyze what students say about their \\ university life experiences in order to identify \\ the role of the library.
}

Research tasks have consisted of a series of online and face-to-face discussions between January and March of 2018 to construct the object of study, generate diversity markers and accomplish the design of an initial approach towards the voices of students.

In this initial period an exploratory probe was conducted through 10 brief interviews in each of the two institutions. With the results, we validated demographic data as well as some students' ideas of their University life around learning, ways of studying, places they visit on a daily basis around the campus, as well as the role of different persons with which they interact around their university life. In addition, with the initial data analysis, we managed to identify large topics and some issues we did not considered before.

\title{
3 RESULTS
}

The guide for a pilot interview that was applied to different individuals and in two group conversations was designed in a face-to-face meeting of the whole research team in the city of Guadalajara. In Mexico City these pilots interviews were replicated and while some coincidences were established, non-shared values were identified.

The most important results are concentrated in two categories, which we have tentatively named: markers of diversity and University life. We identified 31 markers of diversity that distinguish students by their habits and ways of being/living in the University, as well as some aspects of their lifestyles. There are potential dimensions of analysis presented here:

- Intrinsic learning aspects associated with the discipline of study, outstanding students, students with learning disabilities.

- Elements of cultural and linguistic identity associated with students who are foreign, indigenous, migrants.

- Conditions associated with their family situation, such as being married, with children, with siblings who are also students at the University.

- Students with particular health conditions, such as having physical disability, substance abuse, conditions.

- People who in addition to study perform extra class activities such as sports, arts and political activities.

- Those who study and work at the same time within the University or outside of it, being scholarship holders who work or any similar situation.

- Citizens who invest in their commutes and have classes in distinctive schedules (in the morning, the afternoon, or a mixed arrangement), geographic remoteness

- Being in a particular socio-economic condition related to their studies, such as being scholarship holders, having a mixed family income.

- Identified with a specific LGBTQ+ gender or sexual identity.

- Having levels of religiosity that involve very specific practices or beliefs.

About University life, we find recurrences, which we have grouped around the following topics:

- Full University life. Students consider their practice as full of challenges (e.g., time management) and satisfactions, constantly accompanied by other students, it is enjoyable and implies work. It also implies a comprehensive experience that includes sports. The library emerges as a space for individual and group work.

- Learning and studying are not considered in a differentiated way. Students integrate to their own knowledge what is transferred by professors, active-meaningful and dialogic learning is highly valued. Students reflect on the positive and negative aspects of their professors and share their individuality regarding learning. They read and review in preparation for the exams in times they define as the best. They are students for whom dialogue is easy. In relation to the library they mention research tasks and the intensive use of group study cubicles,

- Campus. What is valued in terms of spaces and special programs is: the gym, cafeteria, workspaces as a scholarship holder and advocacy programs. It should be noted that some 
students focus exclusively on the spaces and activities of their field or program. The library appears as an ideal space for homework, individual study and group work.

- Interaction with others. There is a great appreciation of pairs in the University life in all its dimensions, because of the moral support and the strengthening of dialogue with different ways of thinking that implies. The faculty's knowledge and social skills is highly valued, as well as the role of their families. The library is identified as a space that gives opportunity to interact with each other, especially in areas that promote teamwork such as cubicles, informal study and cafeteria areas.

Table 2. Students Uses and Comments about the Library.

\begin{tabular}{|c|c|c|c|}
\hline $\begin{array}{c}\text { Tasks and } \\
\text { Academic Work }\end{array}$ & Collections & Spaces & $\begin{array}{l}\text { Other } \\
\text { services }\end{array}$ \\
\hline $\begin{array}{c}\text { Reading } \\
\text { Newspapers } \\
\text { Teamwork } \\
\text { Homework } \\
\text { Study }\end{array}$ & $\begin{array}{c}\text { Books } \\
\text { Various materials } \\
\text { Research materials } \\
\text { Old books } \\
\text { Audiobooks } \\
\text { Class supplies } \\
\text { Supplies for personal use } \\
\text { Databases }\end{array}$ & $\begin{array}{c}\text { Cubicles } \\
\text { Coffee shop in the library } \\
\text { Spends many hours in the library } \\
\text { It's always visited } \\
\text { There should be more places for } \\
\text { group conversations }\end{array}$ & $\begin{array}{l}\text { Copies } \\
\text { Printing }\end{array}$ \\
\hline
\end{tabular}

\section{CONCLUSIONS}

Taking into account that this is a preliminary phase that reports results on the piloting of collective and individual in-depth interviews, key aspects for the development and direction of the research are confirmed. Fundamental diversity markers are outlined, distancing themselves from a mere demographic logic to select participants for the first phase of the research.

From a fledgling analysis based on the data of the initial probe, we can anticipate relevant aspects involved in the role of the library in the life of students who completely go beyond mere consultation. We believe we will have to rethink forms of talking with students and will need to reorganize and conceptualize their stories to reach best results with in depth interviews. This way we would also achieve better indicators in the different dimensions of analysis.

However, these first clues allow us to understand that for students in our universities, student life is challenging but full of joy and satisfaction; It includes, but goes beyond, what happens in the classroom or with their homework. It also involves many actors, particularly other students in a constant dialogue that integrates both academic and personal spheres, with groups of different size.

We also note that the library is a space appreciated by students not only to investigate bibliographic sources but also for resting, sleeping, reading, performing group work and homework. Students mentioned the need for more space in libraries for informal discussion, in the line of the concept of "learning commons".

At the methodological level, it is worth noting the richness of the discussions between the different research teams that generated a critical reflection based on our teaching experience and perspectives that enlightened views and considerations from different disciplines: Librarianship and Information Sciences, Education, Communication, Physics, and Humanities.

We obtained benefits from the collaborative work, such as strengthening the identification of markers of diversity, achieving a first approach to the object of study and having a nearly final version of markers of diversity. Those markers will allow us to make the selection of students who we will need to interview to ensure the wide listening of the different voices that have life in the University. 


\section{ACKNOWLEDGEMENTS}

Advances in this study are possible because of the financing by the Institute for Research and Development of Education in Universidad Iberoamericana, Mexico City and the direct participation of our libraries' Directors: Teresa Matabuena from the Francisco Xavier Clavigero Library at Universidad Iberoamericana, Mexico City, and Carlos Luna from the Jorge Villalobos Padilla, S.J. Library at ITESO, Jesuit University of Guadalajara. As well as the support provided by Dominique Brun, Director of the Department of Physics and Mathematics of the Universidad Iberoamericana, Mexico City. Thanks to these three instances, the various research activities have been able to carry out and the work teams have been able to maintain a pace of work. We would like to thank our colleague Salvador Carrillo, who is part of our research team. We are especially grateful to the students, as well as to the colleagues in charge of the Program of Multiculturalism and Indigenous Affairs and the Directorate of Community Integration for sharing their stories and relevant information.

\section{REFERENCES}

[1] J. Alonso Arévalo, "La biblioteca en proceso de cambio", BiD: textos universitaris de biblioteconomia i documentació, vol. 36, 2016. Retrieved from http://dx.doi.org/10.1344/BiD2016.36.12

[2] American Library Association, The state of America's libraries: a report from the American Library Association. Chicago: ALA, 2016. Retrieved from http://www.ala.org/news/stateamericas-libraries-report-2016

[3] P. Gazzolo, "Academic libraries take back the power". Information Today. vol.32, no. 2, p.18, 2015.

[4] Association of College and Research Libraries, Documented Library Contributions to Student Learning and Success: Building Evidence with Team-Based Assessment in Action Campus Projects. Prepared by Karen Brown with contributions from Kara J. Malenfant. Chicago: ACRL, 2016. Retrieved from:

http://www.ala.org/acrl/sites/ala.org.acrl/files/content/issues/value/contributions y2.pdf

[5] P. Arellano Douglas, and C.E. Rabinowitz, "Examining the Relationship between facultylibrarian collaboration and first-year students' information literacy abilities". College \& Research Libraries, vol. 77, no. 2, pp. 144-163. 2016. Doi: 10.5860/crl.77.2.144

[6] B. G. Glaser, and A. L. Strauss, The discovery of grounded theory: strategies for qualitative research [EI descubrimiento de teoría fundamentada: estrategias de investigación cualitativa]. New Bruniswick (EU): Aldine Transaction, 2006. (Original work published in 1967).

[7] K. Charmaz, Constructing grounded theory: a practical guide through qualitative analysis [Construyendo teoría fundamentada: una guía práctica a través del análisis cualitativo]. 2ª . Ed. Los Angeles: Sage, 2014.

[8] G. H. Mead, Espíritu, persona y sociedad: desde el punto de vista del conductismo social. México: Paidós, 1993. (Original in English published in 1934).

[8] H. Blumer, Symbolic interactionism: perspective and method [Interaccionismo simbólico: perspectiva y método]. Englewoods Cliffs, New Jersey: Prentice Hall, 1969. 